\title{
The quantitative reconstruction of the palaeoclimate between 5200 and 4300 cal yr BP in the Tianshui Basin, NW China
}

\author{
N. Sun ${ }^{1,2}$ and X. Q. Li ${ }^{1,2}$ \\ ${ }^{1}$ The Laboratory of Human Evolution, Institute of Vertebrate Palaeontology and Palaeoanthropology, \\ Chinese Academy of Sciences, 142 Xizhimenwai street, Beijing, 100044, China \\ ${ }^{2}$ State Lab of Loess \& Quaternary Geology, Institute of Earth Environment, Chinese Academy of Sciences, Hi-Tech Zone, \\ Xi'an, 710075, Shaanxi, China \\ Correspondence to: X. Q. Li (lixiaoqiang@ivpp.ac.cn)
}

Received: 9 August 2011 - Published in Clim. Past Discuss.: 31 August 2011

Revised: 6 March 2012 - Accepted: 7 March 2012 - Published: 22 March 2012

\begin{abstract}
The quantitative reconstruction of the palaeoclimate is a prerequisite for understanding climate processes at time scales of centuries and millennia. Here, the coexistence approach (CA) was applied to reconstruct climatic factors quantitatively based on the fossil charcoal records between 5200 and 4300 cal yr BP in the Tianshui Basin, NW China. The CA analysis showed that the climate of the Tianshui Basin belonged to the northern subtropical zone between 5200 and $4300 \mathrm{cal}$ yr BP. The mean annual temperature (MAT) was approximately $13.2^{\circ} \mathrm{C}$, and the mean annual precipitation (MAP) was approximately $778 \mathrm{~mm}$ between 5200 and 4900 cal yr BP. The MAT was approximately $13.2^{\circ} \mathrm{C}$, and the MAP was approximately $688 \mathrm{~mm}$ between 4800 and $4300 \mathrm{cal} \mathrm{yr} \mathrm{BP}$. The MAT was approximately $2.2^{\circ} \mathrm{C}$ higher than today, and the MAP was approximately $280 \mathrm{~mm}$ higher than today from 5200 to 4900 cal yr BP. The MAT was also approximately $2.2^{\circ} \mathrm{C}$ higher than today from 4800 to 4300 cal yr BP, while the MAP was approximately $196 \mathrm{~mm}$ higher than today. No abrupt cold event occurred between 5200 and 4300 cal yr BP; however, a drought tendency appeared after around 4800 cal yr BP.
\end{abstract}

\section{Introduction}

The Holocene witnessed significant periods in societal developments, and the climate has undergone several fluctuations (Mayewski et al., 2004). The Holocene Megathermal was a much warmer phase in the East Asian monsoon areas, which could be regarded as a palaeo-analogue for future climate predicting (Shi, 1992; Sun et al., 1999; An et al., 2000;
Wang et al., 2005). However, the Holocene Megathermal Maximum occurred asynchronously in different regions (An et al., 2000). It appears earlier in the north and west and later in the south of China and the climate showed a cold-dry tendency after 3000 cal yr BP (Shi et al., 1993; An et al., 2000).

Based on the records of pollen, soil, lake, ice-core, archaeological record, sea level, and so on, Shi et al. (1993) suggested that the warming extent during the Holocene Megathermal Maximum varied throughout China. Comparing the modern climate data, the temperature increased approximately $1{ }^{\circ} \mathrm{C}$ in southern China, $2^{\circ} \mathrm{C}$ in the Yangtze River Valley, and $3{ }^{\circ} \mathrm{C}$ in northern China, northeastern China, and northwestern China. The largest extent of increasing temperature could reach about $4-5^{\circ} \mathrm{C}$ in the southern Tibetan Plateau.

The climate during the Holocene Megathermal showed strong geographic differences in monsoonal China. The Loess Plateau is located in the transition zone of semiarid and semi-humid and forest and grassland or desert and farming-pastoral ecotone ( $\mathrm{Fu}, 1994)$, which is sensitive to Asian monsoon climate and has long been the key area for palaeoclimate research (An et al., 1991; Ding et al., 1995). Many studies of loess-palaeosol sequences have been carried out to reconstruct the palaeomonsoon variations (An and Porter, 1997; Ding et al., 1995; Guo et al., 2002).

To date, a few palaeoclimate reconstructions have been carried out using transfer function from the geological and biological records in the Loess Plateau (Wu et al., 1994; Porter et al., 2001; Lu et al., 2006), which is the popular method to reconstruct the palaeoclimate quantitatively (Webb and Bryson, 1972; Bartlein et al., 1986; Farquar et 
al., 1989; Maher and Roy, 1995). The phytolith records show that the mean annual temperature was $14-16^{\circ} \mathrm{C}(1-$ $3{ }^{\circ} \mathrm{C}$ higher than today), and the mean annual precipitation was $700-800 \mathrm{~mm}$ (100-200 $\mathrm{mm}$ higher than today) during the Holocene Magethermal at Baoji in the southern Loess Plateau (Lu et al., 1996). The ${ }^{10} \mathrm{Be}$ record show that the peak value of the precipitation during the Holocene Magethemal Maximum in Luochuan was almost $800 \mathrm{~mm}$ (Zhou et al., 2007). The records of organic carbon isotopes indicate that the precipitation reached a peak value of $850 \mathrm{~mm}$ in interglacial and decreased to a minimum value of $350 \mathrm{~mm}$ in the last glacial for the past $130 \mathrm{kyr}$ in Weinan (Ning et al., 2008).

However, the quantitative results are uncertain because of the limitation between the proxies and the climate mechanism (Ning, 2010). The transfer functions still include randomness in the implementation of the process. Even the best regression model based on the F-test still lacks sufficient scientific evidence (Zhang, 1988). Therefore, the reliability and effectiveness of the proxy and the method are crucial for quantitative reconstruction of the climate.

Plant growth and vegetation types are controlled by the climatic environment. The botanical records are relatively direct proxies that can be used to reconstruct the climatic factors quantitatively. Forest vegetation is sensitive to the waterheat conditions, especially in the arid and semi-arid areas of northern China. Temperature and precipitation control the formation and succession of the natural forest, the extent of the forest zone, and the height of the vertical vegetation belt (Li and Wang, 1988).

The coexistence approach (CA) is an important method for quantitative reconstruction of the palaeoclimate (Mosbrugger and Utescher, 1997). The reliability of the CA has been validated by previous studies (Li et al., 2003; Yang et al., 2007). One of the most important preconditions is that the climatic tolerance of the fossil plants is similar to the nearest living relative species. The Holocene plants are the result of longterm natural evolution, and their ecological amplitude and climatic tolerance are the same as modern plant types; thus, the CA is well suited for obtaining the quantitative information of climate.

Fossil charcoal comes from the incomplete burning of wood, and the anatomical characters of the original wood are retained (McGinnes et al., 1974). This raises the possibility of much greater precision in the level of taxonomic identification, overcoming the limitation of some plant microfossils (Shackleton and Prins, 1992). Although the fossil charcoal is hard to identify the herbaceous plant and to reflect regional grass vegetation, however, in this way, the fossil charcoal is a good indicator of the wood types, and has the significant potential for reconstructing the local vegetation history and the climatic factors (Shackleton and Prins, 1992; Li et al., 2012), which should be the foundation for reconstructing the regional vegetation and the climate. Some studies of fossil charcoal have been published in China. Most of them focused on the wood types used by the prehistoric people (Wang et al., 2007; Jiang et al., 2009) and few of them discussed the vegetation history (Cui et al., 2002). Until now the quantitative reconstructions of climate from the fossil charcoal records have not been reported on in China.

Here, based on the fossil charcoal records, the coexistence approach (CA) was applied to reconstruct the climatic factors quantitatively, intending to find out the warming magnitude in the Loess Plateau during the Holocene Megathermal, and then to provide convincing data to predict the climate change in the future.

\section{Study area}

The Tianshui Basin is located on the western Loess Plateau and adjacent to the northern Qinling Mountains in NW China, which belongs to the semi-humid region. The mean annual temperature is $11.6^{\circ} \mathrm{C}$, the mean annual precipitation is $491.6 \mathrm{~mm}$, and the growing days is about 248 days per year (Surface Meteorological Data of China, 1971-2000, http://cdc.cma.gov.cn/). The Tianshui Basin developed the loess-palaeosol deposits during the mid-Holocene broadly (Porter and Zhou, 2006).The vegetation was dominated by the sparse-wooded grasslands and grassland (Shang and $\mathrm{Li}$, 2010), but the mixed coniferous and deciduous forest developed in the valley area (Shang and Li, 2010; Li et al., 2012). However, it has been greatly altered because of the long and intense human activities. Today the common natural woody plants are members of the beech, birch, pine, willow, elm, maple, rose and basswood trees. The main herbaceous plants are Grass, Composite, Pea and Buttercup (Wu and Wang, 1983).

The Tianshui Basin is one of the Neolithic centers of northern China where the Neolithic cultures of Yangshao, Majiayao and Qijia developed (Institute of Archaeology of CASS, 1999; Xie, 1985). The Dadiwan and Xishanping sites in the Tianshui Basin are famous for the most complete cultural sequence that preserved numerous Neolithic archaeological remains.

The Xishanping site $\left(34^{\circ} 33^{\prime} 50^{\prime \prime} \mathrm{N}, 105^{\circ} 32^{\prime} 41^{\prime \prime} \mathrm{E}\right.$, $330 \mathrm{~m}$ a.s.l.) is located on a terrace on the southern bank of the Xihe River, and it is approximately $50 \mathrm{~m}$ above the river bed (Fig. 1). The site covers an area of $204800 \mathrm{~m}^{2}$, and the stoneware and pottery are mainly from the Majiayao and Qijia cultures of the Late Neolithic Period (Institute of Archaeology of CASS, 1999; An et al., 2005). Archaeobotanical evidence from the Xishanping site indicates the broadening of early agriculture during the mid-late Neolithic Period (Li et al., 2007a,b).

The Dadiwan site $\left(35^{\circ} 0^{\prime} 29.40^{\prime \prime} \mathrm{N}, \quad 105^{\circ} 54^{\prime} 40.70^{\prime \prime} \mathrm{E}\right.$, $1500 \mathrm{~m}$ a.s.l.) is located on the I and II terraces of the southern bank of the Qingshuihe River to the north of the Tianshui Basin (Fig. 1). Extensive excavation projects have been conducted at the Dadiwan site (Gansu Provincial Institute 
Table 1. Accelerator mass spectrometry (AMS) ${ }^{14} \mathrm{C}$ dates from the Xishanping and Dadiwan sites.

\begin{tabular}{lrlllc}
\hline $\begin{array}{l}\text { Sample } \\
\text { location }\end{array}$ & Depth $(\mathrm{cm})$ & Lab. No & Sample type & $\begin{array}{l}\text { AMS age } \\
\text { (yr BP) }\end{array}$ & $\begin{array}{l}\text { Calibrated age } \\
\text { (cal yr BP, 2 } \sigma \text { ) }\end{array}$ \\
\hline XXP-1 & $60 \mathrm{~cm}$ & TKal3882 & Charcoal & $3900 \pm 35$ & $4236 \sim 4419$ \\
XXP-2 & $130 \mathrm{~cm}$ & TKal3883 & Charcoal & $2785 \pm 30$ & $2839 \sim 2949$ \\
XXP-3 & $345 \mathrm{~cm}$ & TKal3884 & Charcoal & $4430 \pm 35$ & $4870 \sim 5069$ \\
XXP-4 & $490 \mathrm{~cm}$ & TKal3885 & Charcoal & $4855 \pm 35$ & $5579 \sim 5655$ \\
XXP-5 & $560 \mathrm{~cm}$ & TKal3886 & Charcoal & $4360 \pm 35$ & $4845 \sim 4983$ \\
XXP-6 & $570 \mathrm{~cm}$ & TKal3887 & Charcoal & $4400 \pm 35$ & $4859 \sim 5051$ \\
XXP-7 & $585 \mathrm{~cm}$ & TKal3888 & Charred seed & $4430 \pm 100$ & $4833 \sim 5312$ \\
XXP-8 & $620 \mathrm{~cm}$ & TKal3889 & Charred seed & $4490 \pm 35$ & $5035 \sim 5295$ \\
DDW-3 & $420 \mathrm{~cm}$ & OZK647 & Charcoal & $4470 \pm 60$ & $4960 \sim 5306$ \\
DDW-4 & $500 \mathrm{~cm}$ & OZK648 & Charcoal & $4485 \pm 50$ & $5028 \sim 5303$ \\
DDW-5 & $640 \mathrm{~cm}$ & OZK649 & Charcoal & $4370 \pm 50$ & $4842 \sim 5055$ \\
DDW-6 & $760 \mathrm{~cm}$ & OZK650 & Charcoal & $4445 \pm 50$ & $4950 \sim 5288$ \\
DDW-7 & $810 \mathrm{~cm}$ & OZK651 & Charcoal & $4555 \pm 50$ & $5048 \sim 5324$ \\
\hline
\end{tabular}

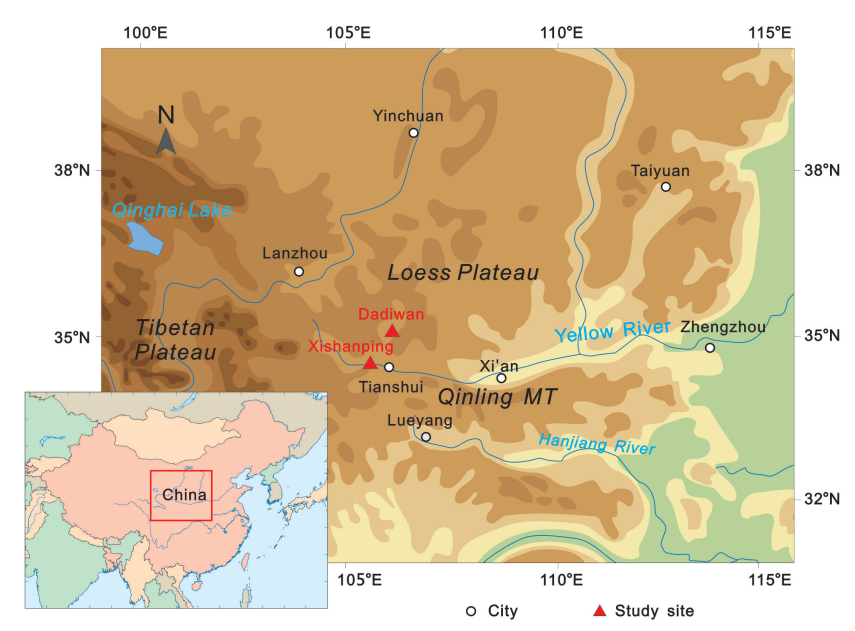

Fig. 1. Location of the study area.

of Archaeology, 2006), which is supposed to be the location of the most developed and continuous cultures: the PreYangshao culture (8000-7000 yr BP), the Yangshao culture (7000-5000 yr BP), the Majiayao culture (5000-4100 yr BP), and the early phase of the Qijia culture (4100-3800 yr BP).

\section{Methods}

\subsection{Age-depth relationship}

A $650 \mathrm{~cm}$ section of continuous and undisturbed cultural sediment on the northern Xishanping site was selected, and the records of the pollen, phytoliths, and seeds have been published (Li et al., 2007a,b). Eight accelerator mass spectrometry (AMS) radiocarbon dates, including six charcoal samples and two charred seeds, were calculated at the University of
Tokyo. The calendar ages were estimated using the radiocarbon calibration program (Reimer et al., 2004). The chronological framework was established by Li et al. (2007a), in which the age-depth model was based on five AMS dates that have the consistent liner relationship. The whole section $(650 \mathrm{~cm})$ covers about a 1000 -year episode between 5250 and $4300 \mathrm{cal}$ yr BP and the ages of each sample were linearly interpolated (Fig. 2, Table 1).

The sediment above $40 \mathrm{~cm}$ had been disturbed by modern agriculture. The fossil charcoals below $450 \mathrm{~cm}$ depth are rare and small, which makes them difficult to identify reliably. Therefore, seven samples were collected from the cultural sediment between 40 and $450 \mathrm{~cm}$ depth with abundant fossil charcoal, corresponding to the period between 4800 and 4300 cal yr BP.

The Dadiwan section is located on the second terrace of the south Qingshuihe River. The total thickness is $820 \mathrm{~cm}$, and the Neolithic culture layer occurs between 400 and $820 \mathrm{~cm}$. Five charcoal AMS radiocarbon dates were calculated at the Australian Nuclear Science and Technology Organisation (ANSTO), and the calendar ages were estimated (Reimer et al., 2004). The sediment between 400 and $820 \mathrm{~cm}$ depth was deposited between 5200 and $4900 \mathrm{cal} \mathrm{yr} \mathrm{BP}$, and it belongs to the late Yangshao and the early Majiayao cultures (Fig. 2, Table 1).

\subsection{Analysis}

The fossil charcoal was recovered using the floatation method (Tsuyuzaki, 1994). Sufficient charcoal fragments were selected for identification and counting. Typically, the number of taxa present in a sample increases sharply while the first few charcoal specimens are examined and then settles down as more fragments are identified (Keepax, 1988; Smart and Hoffman, 1988). Keepax (1988) suggested that 


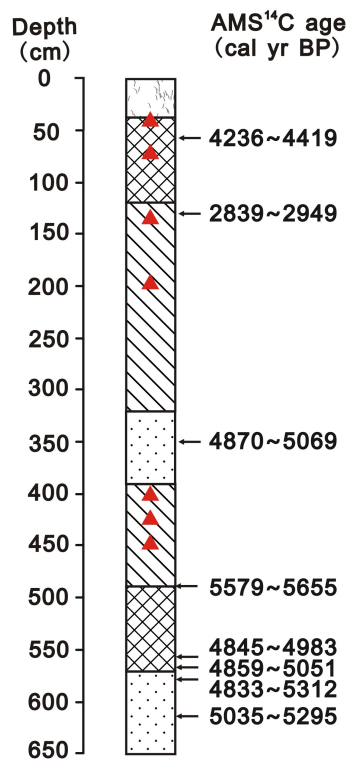

Xishanping section

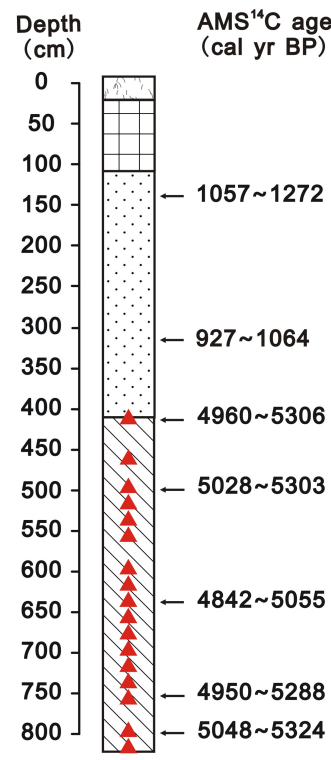

Dadiwan section


$\mathbf{A}$

Sample location

Fig. 2. Stratigraphic sections from the Xishanping and Dadiwan sites and their radiocarbon results.

a minimum of 100 charcoal fragments per sample should be examined in temperate regions to provide a good representation of the types of wood present. Also, the similar examination of fossil charcoal was carried out in the Dadiwan site (including more woody taxa). 127 pieces of fossil charcoal were checked and the saturation curve shows that almost no more new taxa showed up when examining fragments over 100 pieces (Fig. 3). So about 100 pieces of fossil charcoal examined for each sample is suitable for the study area.

At least 100 pieces of fossil charcoal were examined and identified from the Xishanping and Dadiwan sites following the standard procedures. First, pressure fractured charcoal was prepared with a razor blade to produce fresh, clean surfaces to show the transverse, radial and tangential sections (Leney and Casteel, 1975). Then, these charcoal samples were examined under a stereomicroscope and categorized, and one or two samples from each type were photographed under a scanning electron microscope (SEM). The identification of the taxa was carried out according to the reference of wood anatomy atlases.

\subsection{Quantitative study}

The coexistence approach (CA) is used for quantitative study in this paper. The CA finds the nearest living relative species of the fossils and superimposes the climatic tolerance range of each nearest living relative species, the overlap of which

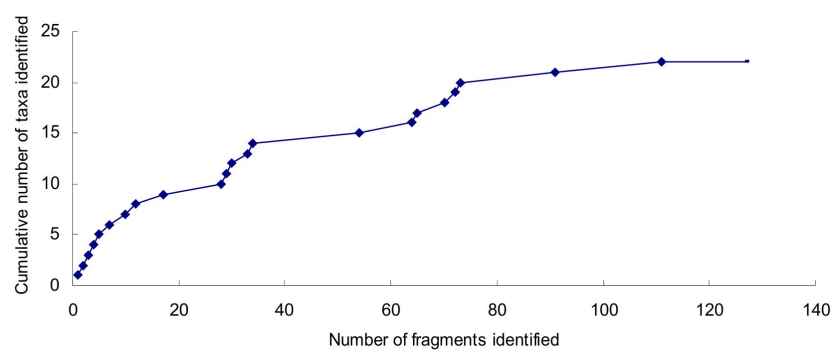

Fig. 3. Identification saturation curve of fossil charcoal from the Dadiwan site, China.

can reflect the palaeoclimate. Generally, the closer the relation between the plant species and fossils, the more taxa identified, which will lead to the higher resolution and accuracy of the climatic data (Mosbrugger and Utescher, 1997).

The tolerance range varies in different plant taxa and can be obtained through the following steps: (1) confirming the distribution range of the plant species (http://frps.plantphoto. $\mathrm{cn} /$; http://www.cvh.org.cn/cms/); (2) using the meteorological data from meteorological stations in the distribution range. Generally one of the meteorological stations is selected from the north, south, east, west border of the distribution range, respectively, and also the one from the highest and lowest elevation, respectively. So, the meteorological data used for each taxa are almost from about six meteorological 




Fig. 4. The abundance ratio of fossil charcoal from the Dadiwan section.

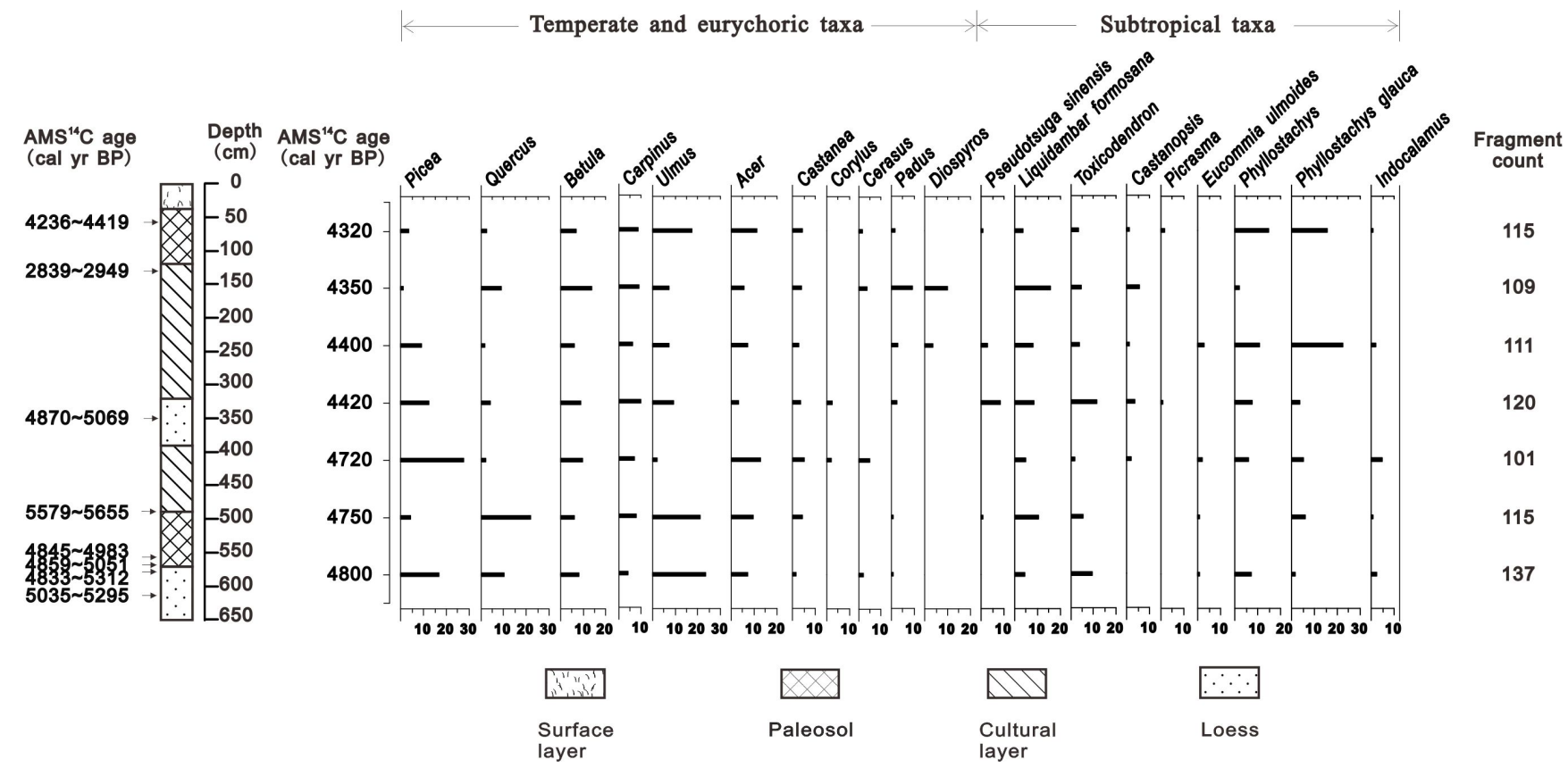

Fig. 5. The abundance ratio of fossil charcoal from the Xishanping section.

stations; and (3) defining the maximum and minimum value of the meteorological data as the plant tolerance range of the climate. Here, three main climatic factors are calculated including mean annual temperature (MAT), mean annual precipitation (MAP) and mean annual relative humidity (RH). The modern climatic factors come from the Surface Meteorological Data of China (1971-2000) (http://cdc.cma.gov.cn/).

\section{Results}

A total of 2307 charcoal fragments were identified, and 34 different taxa were identified in the 17 samples from the Dadiwan section (Fig. 4; Table 2). Betula, Corylus, Ulmus, Quercus mongolica and Acer were present in all 17 samples, whereas Picea brachytyla, Abies, Ostrya, Quercus aliena, Xylosma racemosum, Toxicodendron and Liquidambar formosana were present in 16 samples. Alnus, Sorbus pohuashanensis, Juglans, Gymnocladus chinensis, 
Table 2. The taxa of fossil charcoal and their relative frequencies and abundance ratio from the Dadiwan site.

\begin{tabular}{|c|c|c|c|c|}
\hline Taxa & Absolute fragment count & Abundance ratio (\%) & Ubiquity & Frequency $(\%)$ \\
\hline Abies sp. & 46 & 1.99 & 16 & 94.12 \\
\hline Acer sp. & 246 & 10.66 & 17 & 100.00 \\
\hline Alangium sp. & 15 & 0.65 & 7 & 41.18 \\
\hline Alnus sp. & 78 & 3.38 & 14 & 82.35 \\
\hline Betula sp. & 166 & 7.20 & 17 & 100.00 \\
\hline Castanea sp. & 22 & 0.95 & 9 & 52.94 \\
\hline Cercidiphyllum japonicum & 55 & 2.38 & 15 & 88.24 \\
\hline Corylus sp. & 65 & 2.82 & 17 & 100.00 \\
\hline Cyclobalanopsis sp. & 90 & 3.90 & 15 & 88.24 \\
\hline Ehretia sp. & 48 & 2.08 & 10 & 58.82 \\
\hline Eucommia ulmoides & 74 & 3.21 & 12 & 70.59 \\
\hline Fagus sp. & 5 & 0.22 & 2 & 11.76 \\
\hline Fargesia sp. & 34 & 1.47 & 11 & 64.71 \\
\hline Firmiana sp. & 4 & 0.17 & 4 & 23.53 \\
\hline Gymnocladus chinensis & 84 & 3.64 & 14 & 82.35 \\
\hline Indocalamus sp. & 6 & 0.26 & 5 & 29.41 \\
\hline Juglans sp. & 53 & 2.30 & 12 & 70.59 \\
\hline Liquidambar formosana & 103 & 4.46 & 16 & 94.12 \\
\hline Lonicera sp. & 10 & 0.43 & 4 & 23.53 \\
\hline Osmanthus fragrans & 12 & 0.52 & 6 & 35.29 \\
\hline Ostrya sp. & 118 & 5.11 & 16 & 94.12 \\
\hline Phyllostachys sp. & 97 & 4.20 & 15 & 88.24 \\
\hline Picea brachytyla sp. & 33 & 1.43 & 16 & 94.12 \\
\hline Picrasma sp. & 7 & 0.30 & 5 & 29.41 \\
\hline Prunus sp. & 2 & 0.09 & 1 & 5.88 \\
\hline Prunus armeniaca & 3 & 0.13 & 3 & 17.65 \\
\hline Quercus aliena & 190 & 8.24 & 16 & 94.12 \\
\hline Quercus mongolica & 138 & 5.98 & 17 & 100.00 \\
\hline Sorbus pohuashanensis & 52 & 2.25 & 15 & 88.24 \\
\hline Tilia sp. & 42 & 1.82 & 8 & 47.06 \\
\hline Toxicodendron sp. & 102 & 4.42 & 16 & 94.12 \\
\hline Ulmus sp. & 200 & 8.67 & 17 & 100.00 \\
\hline Vaccinium sp. & 20 & 0.87 & 6 & 35.29 \\
\hline Xylosma racemosum & 87 & 3.77 & 16 & 94.12 \\
\hline Total & 2307 & 100 & 17 & 100 \\
\hline
\end{tabular}

Eucommia ulmoides, Ehretia and Fargesia appeared in more than 10 samples. Figure 4 shows that the abundance of $O s$ trya, Alnus, Gymnocladus chinensis, Toxicodendron, Tilia and Bambusoideae was high (over $11.3 \%$ ) between 5200 and $5100 \mathrm{cal} \mathrm{yr} \mathrm{BP}$, and after $5100 \mathrm{cal}$ yr BP the abundance of these taxa reduced generally. While the abundance of Picea and Abies was relatively low before $5100 \mathrm{cal}$ yr BP, it increased after $5100 \mathrm{cal}$ yr BP.

A total of 808 pieces of charcoal were identified, and 20 different taxa were identified from the samples in the Xishanping section (Fig. 5; Table 3). The most abundant taxa were Picea, Castanea, Betula, Ulmus, Quercus, Carpinus, Toxicodendron, Acer, Liquidambar formosana and Bambusoideae, which were present in all samples. Padus, Castanopsis, Pseudotsuga sinensis, Cerasus and Eucommia ulmoides appeared in 4 samples, and Corylus, Picrasma and Diospyros were only present in two samples. Figure 5 shows that the abundance of Picea, Quercus and Ulmus is high (over $20 \%$ ), while the values of Bambusoideae are low with a range from $1 \%$ to $7 \%$ during $4800 \sim 4600$ cal yr BP. After $4600 \mathrm{cal}$ yr BP, Picea values decreased from a peak value of $28 \%$ to below $5 \%$, Ulmus decreased to about $7 \%$, while Bambusoideae increased significantly to a peak value of $23 \%$. The abundance of Carpinus, Betula, Toxicodendron and Acer was relatively stable the whole time.

The charcoal assemblage at the Dadiwan and Xishanping sites include warm temperate taxa such as Picea, Betula, Acer, Ulmus, Carpinus and Quercus; subtropical evergreen broad-leaved taxa such as Castanopsis and Bambusoideae; and subtropical deciduous taxa such as Liquidambar 

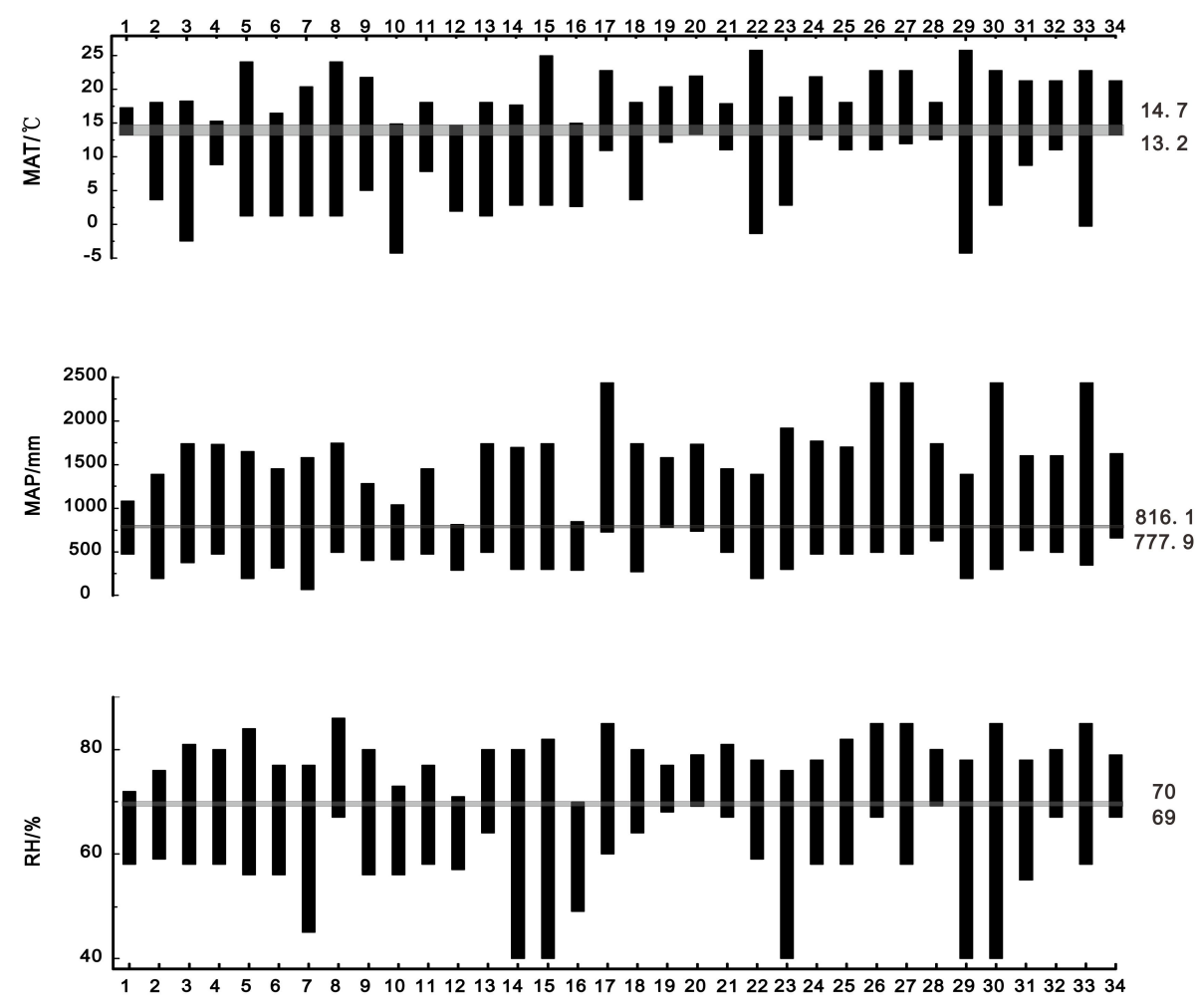

Fig. 6. Coexistence intervals for the Dadiwan section. 1. Picea brachytyla; 2. Abies sp.; 3. Alnus sp.; 4. Ostrya sp.; 5. Betula sp.; 6. Corylus sp.; 7. Ulmus sp.; 8. Acer sp.; 9. Castanea sp.; 10. Quercus mongolica; 11. Quercus aliena; 12. Sorbus pohuashanensis; 13. Juglans sp.; 14. Tilia sp.; 15. Alangium sp.; 16. Armeniaca sibirica; 17. Firmiana sp.; 18. Prunus sp.; 19. Gymnocladus chinensis; 20. Xylosma racemosum; 21. Eucommia ulmoides; 22. Lonicera sp.; 23. Toxicodendron sp.; 24. Liquidambar formosana; 25. Cercidiphyllum japonicum; 26. Ehretia sp.; 27. Cyclobalanopsis sp.; 28. Fagus sp.; 29. Vaccinium sp.; 30. Osmanthus fragrans; 31. Picrasma sp.; 32. Phyllostachys sp.; 33. Fargesia sp.; 34. Indocalamus sp.

formosana and Toxicodendron. Thus, the assemblages of fossil charcoal at the Dadiwan and the Xishanping sites reflect the vegetation type of the evergreen broadleaved and the mixed conifer-broadleaved forests between 5200 and 4300 cal yr BP, which indicates a warmer and wetter climate for the subtropical zone in the Tianshui Basin.

The climatic factors of the Tianshui Basin from 5200 to 4900 cal yr BP were obtained by applying the CA to 34 fossil charcoal taxa from the Dadiwan site (Table 4). The CA results show that the MAT was $13.2-14.7^{\circ} \mathrm{C}$, the MAP was $778-816 \mathrm{~mm}$, and the RH was $69-70 \%$ (Fig. 6). The climatic factors of the Tianshui Basin from 4800 to 4300 cal yr BP were obtained from the CA analysis based on 20 fossil charcoal taxa from the Xishanping site (Table 4). The CA results show that the MAT was $13.2-16.5^{\circ} \mathrm{C}$, the MAP was 688 $1147.8 \mathrm{~mm}$, and the RH was $67-70 \%$ (Fig. 7).

\section{Discussion}

Plant distribution is mainly controlled by climate (Good, 1974). The existence of the plant indicates that the plant's growth can adapt to the climate conditions (Gribbin, 1978).
Vegetation can be formed only if the climate is suitable for each plant species of the community (Wang, 1992). Site catchment analysis indicates that the activity range of prehistoric farming groups was limited to around $5 \mathrm{~km}$ or $1 \mathrm{~h}$ walking distance (Renfrew and Bahn, 1991; Qin et al., 2010); thus, the assemblages of fossil charcoals originated from nearby woody plants, considering there was little evidence of woody plant domestication in the early period, so the fossil charcoal is representative of the natural vegetation. Therefore the fossil charcoal from the archaeological sites is an ideal proxy for reconstructing the local vegetation.

The Xishanping and Dadiwan sites are located on a highland of terrace and have not been disturbed by rivers. In the meantime the selected fossil charcoals are the big size pieces that are hard to be disturbed by wind. Therefore, the assemblages of fossil charcoal from the two sections are efficient to reconstruct the local vegetation and climatic factors.

Here, we examined the distribution range of all the plant taxa present in the Dadiwan and Xishanping section; the climatic range of each taxa was decided from at least six meteorological stations inside the distribution range, which covers almost the whole range of the climatic variable and, therefore, it provided reliable data for this research. 
Table 3. The taxa of fossil charcoal and their relative frequencies and abundance ratio from the Xishanping site.

\begin{tabular}{lrrrl}
\hline Taxa & Absolute fragment count & Abundance ratio(\%) & Ubiquity & Frequency $(\%)$ \\
\hline Acer sp. & 65 & 8.04 & 7 & 100 \\
Betula sp. & 69 & 8.54 & 7 & 100 \\
Carpinus sp. & 61 & 7.55 & 7 & 100 \\
Castanea sp. & 28 & 3.47 & 7 & 100 \\
Castanopsis sp. & 14 & 1.73 & 5 & 71.43 \\
Cerasus sp. & 14 & 1.73 & 4 & 57.14 \\
Corylus sp. & 5 & 0.62 & 2 & 28.57 \\
Diospyros sp. & 15 & 1.86 & 2 & 28.57 \\
Eucommia ulmoides & 7 & 0.87 & 4 & 57.14 \\
Indocalamus sp. & 12 & 1.49 & 5 & 71.42 \\
Liquidambar formosana & 63 & 7.80 & 7 & 100 \\
Padus sp. & 20 & 2.48 & 6 & 85.71 \\
Phyllostachys sp. & 56 & 6.93 & 6 & 85.71 \\
Phyllostachys glauca & 61 & 7.55 & 6 & 85.71 \\
Picea sp. & 86 & 10.64 & 7 & 100 \\
Picrasma sp. & 3 & 0.37 & 2 & 28.57 \\
Pseudotsuga sinensis & 15 & 1.86 & 4 & 57.14 \\
Quercus sp. & 61 & 7.55 & 7 & 100 \\
Toxicodendron sp. & 48 & 5.94 & 7 & 100 \\
Ulmus sp. & 105 & 13.00 & 7 & 100 \\
\hline Total & 808 & 100 & 7 & 100 \\
& & & &
\end{tabular}
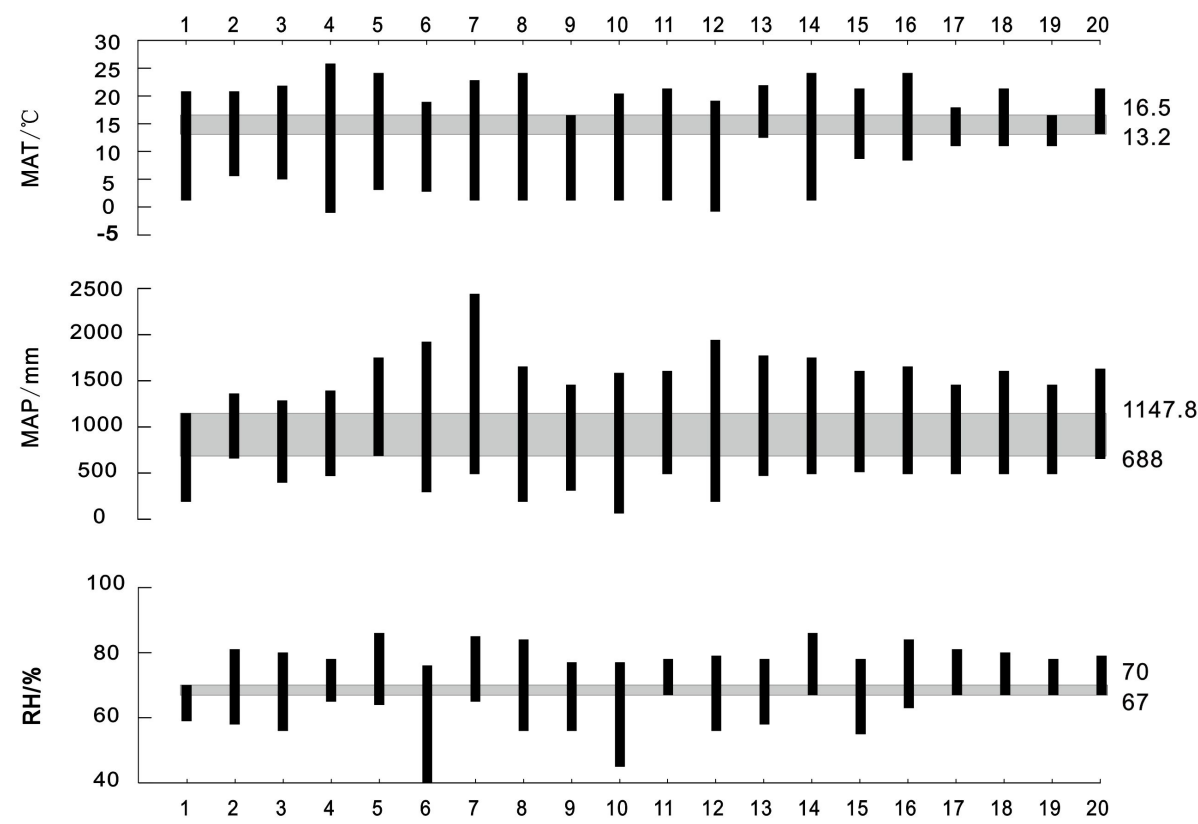

Fig. 7. Coexistence intervals for the Xishanping section. 1. Picea sp.; 2. Pseudotsuga sinensis; 3. Castanea sp.; 4. Quercus sp.; 5. Castanopsis sp.; 6. Toxicodendron sp.; 7. Carpinus sp.; 8. Betula sp.; 9. Corylus sp.; 10. Ulmus sp.; 11. Cerasus sp.; 12. Padus sp.; 13. Liquidambar formosana; 14. Acer sp.; 15. Picrasma sp.; 16. Diospyros sp.; 17. Eucommia ulmoides; 18. Phyllostachys sp.; 19. Phyllostachys glauca; 20. Indocalamus sp. 
Table 4. The climatic range of the single plant taxa.

\begin{tabular}{|c|c|c|c|c|c|c|}
\hline \multirow[t]{2}{*}{ Taxa } & \multicolumn{2}{|c|}{$\mathrm{MAT} /{ }^{\circ} \mathrm{C}$} & \multicolumn{2}{|c|}{$\mathrm{MAP} / \mathrm{mm}$} & \multicolumn{2}{|c|}{$\mathrm{RH} / \%$} \\
\hline & maximum & minimum & maximum & minimum & maximum & minimum \\
\hline Abies sp. & 18.1 & 3.6 & 1391.8 & 191.3 & 76 & 59 \\
\hline Acer sp. & 24.1 & 1.2 & 1749.2 & 491.6 & 86 & 67 \\
\hline Alangium sp. & 25 & 2.8 & 1742.4 & 295.8 & 82 & 40 \\
\hline Alnus sp. & 18.3 & -2.5 & 1742.8 & 373.7 & 81 & 58 \\
\hline Betula sp. & 24.1 & 1.2 & 1651.9 & 191.3 & 84 & 56 \\
\hline Carpinus sp. & 22.8 & 1.2 & 2439.2 & 491.6 & 85 & 65 \\
\hline Castanea sp. & 21.8 & 5 & 1285.2 & 398.5 & 80 & 56 \\
\hline Castanopsis sp. & 24.1 & 3.1 & 1749.2 & 688 & 86 & 64 \\
\hline Cerasus sp. & 21.3 & 1.2 & 1604.5 & 491.6 & 78 & 67 \\
\hline Cercidiphyllum japonicum & 18.1 & 11 & 1704.7 & 471.9 & 82 & 58 \\
\hline Corylus sp. & 16.5 & 1.2 & 1454.6 & 311.7 & 77 & 56 \\
\hline Cyclobalanopsis sp. & 22.8 & 11.9 & 2439.2 & 471.9 & 85 & 58 \\
\hline Diospyros sp. & 24.1 & 8.4 & 1651.9 & 491.6 & 84 & 63 \\
\hline Ehretia sp. & 22.8 & 11 & 2439.2 & 491.6 & 85 & 67 \\
\hline Eucommia ulmoides & 17.9 & 11 & 1454.6 & 491.6 & 81 & 67 \\
\hline Fagus sp. & 18.1 & 12.5 & 1742.4 & 622.3 & 80 & 69 \\
\hline Fargesia sp. & 22.8 & -0.3 & 2439.3 & 344.7 & 85 & 58 \\
\hline Firmiana sp. & 22.8 & 10.9 & 2439.2 & 724.3 & 85 & 60 \\
\hline Gymnocladus chinensis & 20.4 & 12.1 & 1583.5 & 777.9 & 77 & 68 \\
\hline Indocalamus $\mathrm{sp}$. & 21.3 & 13.2 & 1628.5 & 656.3 & 79 & 67 \\
\hline Juglans sp. & 18.1 & 1.2 & 1742.4 & 491.6 & 80 & 64 \\
\hline Liquidambar formosana & 21.9 & 12.5 & 1772 & 471.9 & 78 & 58 \\
\hline Lonicera sp. & 25.8 & -1.4 & 1392.1 & 191.3 & 78 & 59 \\
\hline Osmanthus fragrans & 22.8 & 2.8 & 2439.2 & 295.8 & 85 & 40 \\
\hline Ostrya sp. & 15.3 & 8.8 & 1734.8 & 471.9 & 80 & 58 \\
\hline Padus sp. & 19.1 & -0.8 & 1941 & 191.3 & 79 & 56 \\
\hline Phyllostachys sp. & 21.3 & 11 & 1604.5 & 491.6 & 80 & 67 \\
\hline Phyllostachys glauca & 16.5 & 11 & 1454.6 & 491.6 & 78 & 67 \\
\hline Picea sp. & 20.8 & 1.2 & 1147.8 & 191.3 & 72 & 58 \\
\hline Picea brachytyla & 17.3 & 13.2 & 1084.1 & 471.9 & 72 & 58 \\
\hline Picrasma sp. & 21.3 & 8.7 & 1604.5 & 512 & 78 & 55 \\
\hline Prunus armeniaca & 15 & 2.6 & 848.6 & 286.6 & 70 & 49 \\
\hline Prunus sp. & 18.1 & 2.6 & 1742.4 & 268.9 & 80 & 49 \\
\hline Pseudotsuga sinensis & 20.8 & 5.6 & 1359.4 & 659.7 & 81 & 58 \\
\hline Quercus sp. & 25.8 & -4.3 & 1454.6 & 407.1 & 78 & 56 \\
\hline Quercus aliena & 18.1 & 7.8 & 1454.6 & 471.9 & 77 & 58 \\
\hline Quercus mongolica & 14.9 & -4.3 & 1042.8 & 407.1 & 73 & 56 \\
\hline Sorbus pohuashanensis & 14.7 & 1.9 & 816.1 & 286.6 & 71 & 57 \\
\hline Tilia sp. & 17.7 & 2.8 & 1700.1 & 295.8 & 80 & 40 \\
\hline Toxicodendron sp. & 18.9 & 2.8 & 1921.2 & 295.8 & 76 & 40 \\
\hline Ulmus sp. & 20.4 & 1.2 & 1583.5 & 65.4 & 77 & 45 \\
\hline Vaccinium $\mathrm{sp}$. & 25.8 & -4.3 & 1392.1 & 191.3 & 78 & 40 \\
\hline Xylosma racemosum & 22 & 13.1 & 1736.1 & 763.1 & 79 & 69 \\
\hline
\end{tabular}

Today, the modern subtropical taxa are distributed in the southern area of the Qinling Mountains and the Yangtze River Valley. Therefore, the development of subtropical vegetation between 5200 and $4300 \mathrm{cal} \mathrm{yr} \mathrm{BP}$ in the Tianshui Basin indicates warmer and wetter climate conditions than today. Comparing the modern plant community of typical subtropical vegetation, a few temperate taxa of Sorbus pohuashanensis and Armeniaca sibirica, which almost disappear in the subtropical area, occurred at a relatively high proportion at the Xishanping and Dadiwan sites. Thus, the vegetation in the Tianshui Basin between 5200 and 4300 calyr BP should belong to the northern subtropical zone. 
Table 5. The comparison of the climatic factors among Dadiwan, Xishanping, Tianshui and Lueyang.

\begin{tabular}{lllll}
\hline Locality & $\begin{array}{l}\text { Period } \\
(\text { cal yr BP) }\end{array}$ & MAT ${ }^{\circ} \mathrm{C}$ & MAP/mm & RH/\% \\
\hline Dadiwan & $5200 \sim 4900$ & 13.2 & 778 & 69 \\
Xishanping & $4800 \sim 4300$ & 13.2 & 688 & 67 \\
Tianshui & present & 11 & 491.6 & 67 \\
Lueyang & present & 13.3 & 791.9 & 71 \\
\hline
\end{tabular}

The Dadiwan site from 5200 to 4900 cal yr BP had the following climatic factors: the mean annual temperature (MAT) was between 13.2 and $14.7^{\circ} \mathrm{C}$, the mean annual precipitation (MAP) was between 778 and $816 \mathrm{~mm}$, and the mean annual relative humidity (RH) was $69-70 \%$. The Xishanping site from 4800 to 4300 cal yr BP had the following climatic factors: the MAT was between 13.2 and $16.5^{\circ} \mathrm{C}$, the MAP was between 688 and $1147.8 \mathrm{~mm}$, and the RH was $67-70 \%$. Because the climate of the Tianshui Basin belonged to the northern subtropical zone between 5200 and $4300 \mathrm{cal}$ yr BP, the lower limit value can be regarded as the logical climatic factors to reflect the climate when the climatic tolerance ranges are selected. According to the Surface Meteorological Data of China (1971-2000), the climate between 5200 and $4300 \mathrm{cal} \mathrm{yr} \mathrm{BP}$ in the Tianshui Basin was similar to the modern climate of the Lueyang Basin in the southern Qinling Mountains (Fig. 1; Table 5).

Lueyang $\left(33^{\circ} 19^{\prime} \mathrm{N}, 106^{\circ} 09^{\prime} \mathrm{E}, 1200 \mathrm{~m}\right.$ a.s.l. $)$ is an intermountain basin in the southern Qinling Mountains that belongs to the northern border of the subtropical monsoon climate. Comparing the longitude and latitude between the Lueyang and the Tianshui Basin $\left(34^{\circ} 33^{\prime} 50^{\prime \prime} \mathrm{N}\right.$, $105^{\circ} 32^{\prime} 41^{\prime \prime} \mathrm{E}$ ), the difference of latitude is approximately $1.2^{\circ}$. Thus, we conclude that the subtropical vegetation zone expanded northward by approximately $1.2^{\circ}$ and reached the northern Qinling Mountains between 5200 and 4300 cal yr BP.

Comparing the climatic factors from the CA to the modern meteorological data in the Tianshui Basin, the MAT was approximately $2.2^{\circ} \mathrm{C}$ higher than today, and the MAP was approximately $280 \mathrm{~mm}$ higher than today from 5200 to $4900 \mathrm{cal}$ yr BP. The MAT was also approximately $2.2^{\circ} \mathrm{C}$ higher than today from 4800 to 4300 cal yr BP, while the MAP was approximately $196 \mathrm{~mm}$ higher than today, and the RH decreased approximately $2 \%$ after $4800 \mathrm{cal}$ yr BP. Therefore, the MAT of the Tianshui Basin was roughly constant, suggesting that no drastic climate event occurred from 5200 to $4300 \mathrm{cal}$ yr BP. However, the MAP decreased approximately $80 \mathrm{~mm}$ and the RH decreased $2 \%$ after $4800 \mathrm{cal}$ yr BP. These correspond to many records in the same period, for example the low lake level in northeast and middle-eastern China (Xu et al., 1988; Cui et al., 1992), decrease of arboreal and shrub pollen in Daihai Basin (Xu et al., 2004) and the western Loess Plateau (An et al., 2003). Also, pollen records from north China during this period show that the vegetation zone generally shifted southwards (Sun et al., 1999; Ni et al., 2010), all of which is consistent with the weakening of the East Asian monsoon that led to the precipitation decrease after $5000 \mathrm{yr} \mathrm{BP}$ (Wang et al., 2005; Fleitmann et al., 2007).

\section{Conclusions}

The palaeoclimatic factors in the Tianshui Basin were obtained by applying the CA method using fossil charcoal data. The results indicate that the climate between 5200 to $4300 \mathrm{cal}$ yr BP was warmer than today by about $2.2^{\circ} \mathrm{C}$, while it was moister than today by some $280 \mathrm{~mm} \mathrm{yr}^{-1}$ from 5200 and $4900 \mathrm{cal} \mathrm{yr} \mathrm{BP}$, and some $190 \mathrm{~mm} \mathrm{yr}^{-1}$ from 4800 to 4300 cal yr BP. No abrupt cold event was found in the data for the period considered. These climate conditions are similar to modern climate around Lueyang in the southern Qinling Mountains. Taken together, these results suggest that higher temperatures could enhance the East Asian monsoon, and then bring increasing precipitation.

Acknowledgements. We greatly appreciate the valuable comments from two reviewers, S. Leroy and anonymous reviewer, and from the Editor of CP, M. Claussen. This work was supported by the National Key Basic Research Fund (No. 2010CB9502004), the National Natural Science Found (No. 41172161) and Innovation Program of CAS (KZCX2-YW-Q1-03).

Edited by: M. Claussen

\section{References}

An, C. B., Feng, Z. D., and Tang, L. Y.: Evidence of a humid midHolocene in the western part of Chinese Loess Plateau, Chinese Sci. Bull., 48, 2472-2479, 2003.

An, C. B., Tang, L. Y., Barton, L., and Chen, F. H.: Climate change and cultural response around $4000 \mathrm{cal} \mathrm{yr} \mathrm{BP}$ in the western part of Chinese Loess Plateau, Quaternary Res., 63, 347-352, 2005.

An, Z. S. and Porter, S. C.: Millennial-scale climatic oscillations during the last interglaciation in central China, Geology, 25, 603606, 1997.

An, Z. S., Kukla, J. G., Porter, C. S., and Xiao, J. L.: Magnetic susceptibility evidence of monsoon variation on the Loess Plateau of central China during the last 130,000 years, Quaternary Res., 36, 29-36, 1991.

An, Z. S., Kutzbach, J. E., Wu, X. H., Wang, S. M., Liu, X. D., Li, X. Q., Zhou, W. J., and Porter, C. S.: Asynchronous Holocene optimum of the East Asian monsoon, Quaternary Sci. Rev., 19, 743-762, 2000.

Bartlein, P., Prentice, I., and Webb III., T.: Climatic response surfaces from pollen data for some eastern North American Taxes, J. Biogeogr. , 13, 35-57, 1986. 
Cui, H. T. and Kong, Z. C.: A preliminary analysis about the climatic fluctuation of Holocene Megathermal in the centre and eastern parts of Inner Mongolia, in: The Climates and Environments of Holocene Megathermal in China, edited by: Shi, Y. F. and Kong, Z. C., China Ocean Press, Beijing, 72-79, 1992.

Cui, H. T., Li, Y. Y., Hu, J. M., Yao, X. S., and Li, Y.: Vegetation reconstruction of Bronze Age by using microscopic structure of charcoals, Chinese Sci. Bull., 47, 2014-2017, 2002.

Ding, Z. L., Liu, T. S., Rutter, W. N., Yu, Z. W., Guo, Z. T., and Zhu, R. X.: Ice-volume forcing of East Asian Winter Monsoon variations in the past 800,000 years, Quaternary Res., 44, 149159, 1995.

Farquhar, G., Ehleringer, J., and Hubic, K.: Carbon isotope discrimination and photosynthesis, Annual Rev. Plant Physiol., 40, 503-537, 1989.

Fleitmann, D., Burns, S. J., Mangini, A., Mudelsee, M., Kramers, J., Villa, I., Neff, U., Al-Subbary, A. A., Buettner, A., Hippler, D., and Matter, A.: Holocene ITCZ and Indian monsoon dynamics recorded in stalagmites from Oman and Yemen (Socotra), Quaternary Sci. Rev., 26, 170-188, 2007.

Fu, C. B.: An aridity trend in China in association with global warming, in: Climate-Biosphere Interaction: Biogenic Emission and Environmental Effects of Climate Change, edited by: Richard, Z. G., John Wiley \& Sons Inc., New York, 1-17, 1994.

Gansu Provincial Institute of Archaeology: Dadiwan in Qin'an, Cultural relics publishing house, Beijing, 2006.

Good, R.: The Geography of the flowering plants, 4th Edn., Longman Group Ltd, London, 1974.

Gribbin, J.: Climate Change, Cambridge University Press, New York, 1978.

Guo, Z. T., Ruddiman, W. F., Hao, Q. Z., Wu, H. B., Qiao, Y. S., Zhu, R. X., Peng, S. Z., Wel, J. J., Yuan, B. Y., and Llu, T. S.: Onset of Asian desertification by $22 \mathrm{Myr}$ ago inferred from loess deposits in China, Nature, 416, 159-163, 2002.

Institute of Archaeology of CASS: Shizhaocun and Xishanping, Chinese Encyclopaedia Press, Beijing, 1999.

Jiang, H. E., Zhang, Y. B., Li, X., Yao, Y. F., Ferguson, K. D., Lü, E. G., and Li, C. S.: Evidence for early viticulture in China: proof of a grapevine (Vitis vinifera L., Vitaceae) in the Yanghai Tombs, Xinjiang, J. Archaeol. Sci., 36, 1458-1465, 2009.

Keepax, C. A.: Charcoal analysis with particular reference to archaeological sites in Britain, $\mathrm{PhD}$. thesis, University of London, 1988.

Leney, L. and Casteel, R. W.: Simplified procedure for examining charcoal specimens for identification, J. Archaeol. Sci., 2, 153$159,1975$.

Li, C. S., Wang, Y. F., and Sun, Q. G.: The quantitative reconstruction of palaeoenvironments and palaeoclimates based on plants, Chinese Bull. Bot., 20, 430-438, 2003.

Li, S. K. and Wang, S. L.: Study on the agro-pasturing climate boundary line in semi-arid area of northern China, in: Study on the natural resources in arid and semi-arid areas of China, Science press, Beijing, 108-124, 1988.

Li, X. Q., Dodson, J., Zhou, X. Y., Zhang, H. B., ans Masutomoto, R.: Early cultivated wheat and broadening of agriculture in Neolithic China, Holocene, 17, 555-560, 2007a.

Li, X. Q., Zhou, X. Y., Zhou, J., Dodson, J., Zhang, H. B., and Shang, X.: The earliest archaeobiological evidence of the broadening agriculture in China recorded at Xishanping site in Gansu
Province, Sci. China Ser. D, 50, 1707-1714, 2007 b.

Li, X. Q., Sun, N., Dodson, J., Zhou, X. Y., and Zhao, K. L.: The Vegetation Characteristics in the Western Loess Plateau during the mid-Holocene, based on Charcoal Fossils, Veg. Hist. Archaeobot., doi:10.1007/s00334-011-0344-9, in press, 2012.

Lu, H. Y., Wu, N., Liu, T. S., Han, J. M., and Qin, X. G.: Seasonal changes on phytolith assemblage in loess in Baoji since $150 \mathrm{ka}$, Sci. China Ser. D, 26, 131-136, 1996.

Lu, H. Y., Wu, N. Q., Yang, X. D., Jiang, H., Liu, K. B., and Liu, T. S.: Phytoliths as quantitative indicators for the reconstruction of past environmental conditions in China I: phytolith-based transfer functions, Quaternary Sci. Rev., 25, 945-959, 2006.

Maher, B. and Roy, T.: Palaeorainfall reconstructions from pedogenic magnetic susceptibility, Quaternary Res., 44, 383-391, 1995.

Mayewski, P. A., Rohling, E. E., Curt Stager, J., Karlén, W., Maasch, K. A., David Meeker, L., Meyerson, E. A., Gasse, F., van Kreveld, S, Holmgren, K., Lee-Thorp, J., Rosqvist, G., Rack, F., Staubwasser, M., Schneider, R. R., and Steig, E. J.: Holocene climate variability, Quaternary Res., 6262, 243-255, 2004.

McGinnes, E. A., Szopa, P. S., and Phelps, J. E.: Use of scanning election microscopy in studies of wood charcoal formation, Scanning Electron Microscopy, AMF O'Hare, Chicago, 469476, 1974.

Mosbrugger, V. and Utescher, T.: The coexistence approach a method for quantitative reconstructions of Tertiary terrestrial palaeoclimate data using plant fossils, Palaeogeogr. Palaeocl., 134, 61-86, 1997.

Ni, J., Yu, G., Harrison, S. P., and Prentice, I. C.: Palaeovegetation in China during the late Quaternary: Biome reconstructions based on a global scheme of plant functional types, Palaeogeogr. Palaeocl., 289, 4-61, 2010.

Ning, Y. F.: Methods in Quantitative reconstruction of the palaeoclimate on the Chinese Loess Plateau, Geol. Rev., 56, 99-104, 2010.

Ning, Y. F., Liu, W. G., and An, Z. S.: A 130-ka reconstruction of precipitation on the Chinese Loess Plateau from organic carbon isotopes, Palaeogeogr. Palaeocl., 270, 59-63, 2008.

Porter, S. C. and Zhou, W. J.: Synchronism of Holocene East Asian monsoon variations and North Atlantic drift-ice tracers, Quaternary Res., 65,443-449, 2006.

Porter, S. C., Hallet, B., Wu, X. H., and An, Z. S.: Dependence of Near-Surface Magnetic Susceptibility on Dust Accumulation Rate and Precipitation on the Chinese Loess Plateau, Quaternary Res., 55, 271-283, 2001.

Qin, L., Fuller, D. Q., and Zhang, H.: Modelling wild food resource catchments amongst early farmers: case studies from the lower Yangtze and central China, Quaternary Sci., 30, 245-261, 2010.

Reimer, P. J., Baillie, M. G. L., Bard, E., Baylis, A., Beck, J. W., Bertrand, C. J. H., Blackwell, P. G., Buck, C. E., Burr, G. S., Cutler, K. B., Damon, P. E., Edwards, R. L., Fairbanks, R. G., Friedrich, M., Guilderson, T. P., Hogg, A. G., Hughen, K. A., Kromer, B., McCormac, G., Manning, S., Ramsey, C. B., Reimer, R. W., Remmele, S., Southon, J. R., Stuiver, M., Talamo, S., Taylor, F. W., Plicht, J. V. D., and Weyhenmeyer, C. E.: IntCal04 terrestrial radiocarbon age calibration, $0 \sim 26$ cal. kyr BP, Radiocarbon, 46, 1029-1058, 2004.

Renfrew, C. and Bahn, P.: Archaeology Theories, Methods and Practice, Thames and Hudson Ltd, London, 1991. 
Shackleton, C. M. and Prins, F.: Charcoal analysis and the principle of least effort - a conceptual model, J. Archaeol. Sci., 19, 631637, 1992.

Shang, X. and Li, X. Q.: Holocene vegetation characteristics of the southern Loess Plateau in the Weihe River valley in China, Rev. Palaeobot. Palynol., 160, 46-52, 2010.

Shi, Y. F.: Glaciers and glacial geomorphology in China, Z. Geomorphol., 86, 51-63, 1992.

Shi, Y. F., Kong, Z. C., and Wang, S. M.: The important climatic fluctuations and events in China during the Holocene Megathermal, Sci. China Ser. B, 23, 865-873, 1993.

Smart, T. L. and Hoffman, E. S.: Environmental interpretation of archaeological charcoal, in: Current Palaeoethnobotany, edited by: Hastorf, C. A. and Popper, V. S., University of Chicago Press, Chicago and London, 165-205, 1988.

Sun, X. J., Song, C. Q., and Chen, X. D.: "China Quaternary Pollen Database" (CPD) and "BIOME 6000" project, Adv. Earth Sci., 14, 407-411, 1999.

Tsuyuzaki, S.: Rapid seed extraction from soils by a flotation method, Weed Res., 34, 433-436, 1994.

Wang, H. S.: Floristic plant geography, Science Press, Beijing, 1992.

Wang, S. Z., Wang, Z. L., and Xu, H.: A study of the wood charcoal unearthed in Erlitou site, Cult. Rel. Central China, 3, 93-99, 2007.

Wang, Y. J., Cheng, H., Edwards, R. L., He, Y. Q., Kong, X. G., An, Z. S., Wu, J. Y., Kelly, M. J., Dykoski, C. A., and Li, X. D.: The Holocene Asian Monsoon: links to solar changes and North Atlantic Climate, Science, 308, 854-857, 2005.

Webb, T. and Bryson, R.: Late and post glacial climate change in the Nort hern Midwest, USA: Quantitative estimates derived from fossil pollen spectra by multivariate statistic analysis, Quaternary Res., 2, 70-115, 1972.
Wu, N. Q., Lu, H. Y., Sun, X. J., Guo, Z. T., Liu, J. Q., and Han, J. M.: Climate transfer function from opal phytolith and its application in palaeoclimate reconstruction of China loess-palaeosol sequence, Quaternary Sci., 3, 270-279, 1994.

Wu, Z. Y. and Wang, H. S.: Botanical geography, Science Press, Beijing, 1983.

Xie, D. J.: The types of the Majiayao culture and the related issues, Archaeol. Cult. Rel., 1, 63-71, 1985.

Xu, Q. H., Chen, S. Y., Kong, Z. C., and Du, N. Q.: Preliminary discussion of vegetation succession and climate change since the Holocene in the Baiyangdian Lake district, Acta Phytoecol. Geobot. Sin., 12, 143-151, 1988.

Xu, Q. H., Xiao, J. L., Toshio, N., Yang, X. Y., Zheng, Z. H., Liang, W. D., Li, Y. C., and Yoshio, I.: Pollen evidence of vegetation and climate changes in Daihai Lake area during the Holocene, J. Glaciol. Geocryol., 26, 73-80, 2004.

Yang, J., Wang, Y. F., Spicer, R. A., Mosbrugger, V., Li, C. S., and Sun, Q. G.: Climatic reconstruction at the Miocene Shan Wang Basin, China, using leaf margin analysis, CLAMP, coexistence approach, and over lapping distribution analysis, Am. J. Bot., 94, 599-608, 2007.

Zhang, Q. R.: Applied regression analysis, Geology Press, Beijing, p. 424, 1988.

Zhou, W. J., Priller, A., Beck, J. W., Wu, Z. K., Chen, M. B., An, Z. S., Kutschera, W., Xian, F., Yu, H. G., and Liu, L: Disentangling geomagnetic and precipitation signals in an 80-kyr Chinese loess record of $10 \mathrm{Be}$, Radiocarbon, 49, 139-160, 2007. 